\title{
Technology, slavery and the Falmouth Water Company of Jamaica, 1799-1805
}

\author{
Aaron Graham
}

\author{
Ascription; Dr Aaron Graham is a Leverhulme Early Career Fellow at University \\ College London, Gower Street, London, WC1E 6BT, UK. \\ Email: aaron.graham@ucl.ac.uk
}

\begin{abstract}
$\underline{\text { Abstract }}$
Slave societies such as Jamaica were among the earliest regions to adopt new technologies, suggesting that slavery was not synonymous with economic backwardness. This article uses the efforts of the Falmouth Water Company to adopt the new hydraulic ram between 1799 and 1805 to show that this process was also not restricted to the plantation sector and that the island possessed an unexpected capacity for technological adaption. This was based on local skills in mechanical and civil engineering derived from the plantation sector, and wider political and financial background that supported innovation when the right conditions were in place.
\end{abstract}

\section{$\underline{\text { Keywords }}$}

slavery; technology; invention; Jamaica; urbanisation; utilities

The first steam engine in the Americas was erected in New Jersey at the Schuyler Copper Mine in 1753. The second was set up in Jamaica in 1768 to grind sugar cane produced by slaves, making the West Indies one of the earliest regions outside Europe to embrace this powerful new technology. ${ }^{1}$ Noel Deerr, Veront Satchell and Jennifer

\footnotetext{
${ }^{1}$ Noel Deerr and Alexander Brooks, 'The early use of steam power in the cane sugar industry', Transactions of the Newcomen Society, 21 (1940) pp. 11-21; Veront Satchell, 'Early use of steam power in the Jamaican sugar industry, 1768-1810', Transactions of the Newcomen Society, 67 (1995) pp. 221-31; Jennifer Tann, 'Steam and sugar: the diffusion of the stationary steam engine to the
} 
Tann, among others, have shown that the process was one of innovation and adaption as well as adoption. 'Experimentation took place', notes Satchell, for example, '... [and] planters themselves were actively investigating, seeking further information and actually adapting steam engines on their estates', such as by increasing the size of boilers in steam engines to burn cane trash rather than coal. ${ }^{2}$ These findings have undermined established views of the British West Indies as technological backwaters and failed societies and contributed to a wider reassessment of the links between slavery and industrialisation. ${ }^{3}$ Dale Tomich, Richard Follett, Robert Gudmestad and many others have challenged the wider orthodoxy established by Eugene Genovese that all slavery was incompatible with technological innovation, and shown that inventions such as the steam engine and the vacuum pan were eagerly adopted by planters in Saint Domingue, Cuba and Louisiana from the late eighteenth century onwards. ${ }^{4}$ Yet the focus so far has been almost wholly on the plantation sector. A

Caribbean sugar industry, 1770-1840', History of Technology, 19 (1997) pp. 63-84. For a wider study of steam engine diffusion, see Jennifer Tann and M.J. Breckin, 'The international diffusion of the Watt Engine, 1775-1825', Economic History Review, 31 (1978) pp. 541-64.

${ }^{2}$ Satchell, 'Early use of steam power', pp. 221-31

${ }^{3}$ Richard B. Sheridan, 'Changing sugar technology and the labour nexus in the British Caribbean, 1750-1900, with special reference to Barbados and Jamaica', Nieuwe West-Indische Gids / New West Indian Guide, 63 (1989) pp. 59-93. For examples of older interpretations, see Lowell J. Ragatz, The fall of the planter class in the British Caribbean, 1763-1833: a study in social and economic history (New York; London; The Century Co, 1928) pp. 62-80; Gisela Eisner, Jamaica, 1830-1930: a study in economic growth (Manchester; Manchester University Press, 1961) pp. 296-8

${ }^{4}$ Peter Boomgaard and Gert J. Oostindie, 'Changing sugar technology and the labour nexus: the Caribbean, 1750-1900', Nieuwe West-Indische Gids / New West Indian Guide, 63 (1989) pp. 3-22; Dale W. Tomich, Slavery in the circuit of sugar: Martinique and the world economy, 1830-1848 (Baltimore, MD; Johns Hopkins University Press, 1990) pp. 189-213; Jonathan Curry-Machado, Cuban sugar 
close study of the Falmouth Water Company of Jamaica and its efforts to introduce the hydraulic ram into the island between 1799 and 1805 develops this further and confirms that societies built on slavery were able to adopt and adapt technology in areas not directly connected to this part of their economy, and that they therefore possessed an unexpectedly broad capacity for technological innovation.

This matters because slave societies have been an important test for wider theories of technological innovation and diffusion. Robert Allen argues that the rise of technology was a product of demand and that high wages in Britain encouraged manufacturers to adopt new machines that reduced labour requirements and saved money. ${ }^{5}$ By contrast, Joel Mokyr has argued that innovation reflected the unique supply of human capital of British society, which encouraged and allowed inventors to translate their ideas into reality. ${ }^{6}$ Studies of technological diffusion have relied on similar calculations of supply and demand. Doron Ben Atar and Ross Thomson used 'epidemic theory' to argue that diffusion reflected growing knowledge of new inventions, but others would accept Nathan Rosenberg's conclusion that diffusion

\footnotetext{
industry: transnational networks and engineering migrants in mid-nineteenth century Cuba (New York; Palgrave Macmillan, 2011) pp. 23-47; Richard J. Follett, The sugar masters: planters and slaves in Louisiana's cane world, 1820-1860 (Baton Rouge; Louisiana State University Press, 2005) pp. 1445; James McClellan, Colonialism and science: Saint Domingue and the Old Regime (Chicago; University of Chicago Press, 2010) pp. 63-74; Robert Gudmestad, 'Technology and the world the slaves made', History Compass, 4 (2006) pp. 373-83

${ }^{5}$ Robert C. Allen, The British industrial revolution in global perspective (Cambridge; Cambridge University Press, 2009)

${ }^{6}$ Joel Mokyr, The enlightened economy: Britain and the industrial revolution 1700-1850 (London; Penguin, 2009)
} 
reflected a balance of supply and demand that shifted continually during this period. ${ }^{7}$ All agree that by reducing wages and misusing human capital, slave societies had fewer incentives to innovate and so did not industrialise. ${ }^{8}$ More recently though, Gudmestad and others have concluded that slave societies innovated widely but in different ways because they faced a different balance of supply and demand; 'slavery', he argues, 'served as a filter for economic choices'. 9 Planters across the Americas therefore favoured and supported new technologies such as the cotton gin or the vacuum pan that could increase the efficiency and output of the plantation system without undermining the social and racial divisions that held the enslaved population in check. What remains unclear is how far this was true outside the main plantation sector and thus the capacity of societies such as Jamaica to embrace technological solutions to other local social and economic problems.

\footnotetext{
${ }^{7}$ Nathan Rosenberg, 'Factors affecting the diffusion of technology', Explorations in Economic History, 10 (1972) pp. 3-33; Jayati Sarkar, 'Technological diffusion: alternative theories and historical evidence', Journal of Economic Surveys, 12 (1998) pp. 131-76; P.A. Geroski, 'Models of technology diffusion', Research Policy, 29 (2000) pp. 603-25; Claude Diebolt, Tapas Mishra, and Mamata Parhi, Dynamics of distribution and diffusion of new technology: a contribution to the historical, economic and social route of a developing economy (London; Springer, 2016) pp. 15-44. For Thomson and Ben Atar, see Doron Ben-Atar, Trade secrets: intellectual piracy and the origins of American industrial power (New Haven, CT; Yale University Press, 2004); Ross Thomson, Structures of change in the mechanical age: technological innovation in the United States, 1790-1865 (Baltimore, MD; Johns Hopkins University Press, 2009)

${ }^{8}$ See above n. 4 and Susanna Delfino and Michele Gillespie, 'Introduction', in idem (eds), Technology, innovation and Southern industrialization: from the antebellum era to the computer age (Columbia, MO; University of Missouri Press, 2008) pp. 1-8; Gudmestad ‘Technology’ pp. 373-83.

${ }^{9}$ Gudmestad, ‘Technology’ p. 380.
} 
The Falmouth Water Company is an apt focus for this study because, as Leslie Tomory has recently concluded, utility companies such as waterworks were important centres for technological innovation and diffusion in Britain and North America during the eighteenth century. ${ }^{10}$ 'The intensification of network-supplied water into homes in London moved this most mundane of consumer goods into a commercial market', he notes, '[which was] run by companies and made possible by technological innovation'. ${ }^{11}$ In North America, waterworks in New York in 1774 and Philadelphia in 1799 were some of the first ventures to embrace technology and replace horse-mills and waterwheels with steam engines. ${ }^{12}$ By 1818 , for example, there were two steam engines at Fairmont near Philadelphia capable of pumping three million gallons of water per day, and Darwin Stapleton has argued that they became an important vector for the transfer of engineering skills. The letters from the waterworks in Falmouth to Boulton and Watt suggest that the slave society of Jamaica could likewise support the diffusion of the new hydraulic technologies, and that even the innate caution of local planters could be overcome by useful innovations that promised greater productivity

\footnotetext{
${ }^{10}$ Leslie Tomory, 'London's water supply before 1800 and the roots of the networked city', Technology and Culture, 56 (2015) pp. 704-37; Leslie Tomory, 'Water technology in eighteenth-century London: the London Bridge Waterworks', Urban History, 42 (2015) pp. 381-404. For an overview of the history of London's water supply, see John Graham-Leigh, London's water wars: the competition for London's water supply in the nineteenth century (London; Francis Boutle, 2000) pp. 3-36

${ }^{11}$ Tomory, 'London's water supply', p. 713

${ }^{12}$ Nelson Manfred Blake, Water for the cities: a history of the urban water supply problem in the United States (Syracuse, NY; Syracuse University Press, 1956) pp. 78-83; Gerard T. Koeppel, Water for Gotham: a history (Princeton, NJ; Princeton University Press, 2000) pp. 36-49; Darwin H. Stapleton,
} The transfer of early industrial technologies to America (Philadelphia, PA; American Philosophical Society, 1987) pp. 59-71. 
or efficiency, especially at a time when high prices for sugar were encouraging planters to look for ways to increase production by developing marginal lands. Put simply, the experience of the Falmouth Water Company shows that slave societies such as Jamaica had much the same human and social resources to innovate and industrialise as either England or New England, and could do so when the supply of labour and innovations and the demand for each were closely enough aligned to offer a sufficient incentive to inventors or importers of technology.

$-\mathrm{I}-$

Although settlement in Jamaica was initially concentrated in the south-eastern part of the island, the northern and western frontiers were steadily opened up from the early eighteenth century, and ports such as Savanna-la-Mar, Lucea and Montego Bay had developed by the late eighteenth century as important outlets for plantation produce. ${ }^{13}$ The parish of Trelawney was created in 1770 and its capital placed inland at Martha Brae, but it soon became clear that the parish needed a coastal settlement to support the export of sugar, molasses, rum and coffee, and the town of Falmouth was founded in the 1790s for this purpose. 'It has of late increased in population and building[s] to an extraordinary degree', one resident wrote in 1799, 'and is in aspect of trade and

\footnotetext{
${ }^{13}$ Nadine Hunt, 'Expanding the frontiers of western Jamaica through minor Atlantic ports in the eighteenth century', Canadian Journal of History, 45 (2010) pp. 485-502. Richard B. Sheridan, Sugar and slavery: an economic history of the British West Indies, 1623-1775 (London; Caribbean University Press, 1974) pp. 208-33, 459-62; Dan Ogilvie, History of the parish of Trelawney (Kingston, Jamaica; privately printed, 1954) pp. 1-21. Ogilvie had access to the vestry minutes of Trelawney parish before they were destroyed in 1926 when the court house in Falmouth burnt down.
} 
shipping the second port of the island of Jamaica'. ${ }^{14}$ Three acts of the Jamaican legislature in 1794 and 1795 allowed the parish vestry to raise $£ 10,000$ in taxation for the construction of a church, parsonage and courthouse; to collect a tax from shipping for the maintenance of the harbour; and to make municipal regulations for policing, fire-watching, liquor licensing, street cleaning and refuse collection. ${ }^{15}$ The vestry was also granted the power to acquire land by compulsory purchase to convey water by an aqueduct from the river at Martha Brae for the use of the town. ${ }^{16}$ Another act in 1799 allowed the vestry to appoint a force of nightwatchmen; to hire scavengers to clear the streets; to establish a marine hospital for sailors; and to set up markets for fish and beef. ${ }^{17}$ The town therefore saw rapid improvements calculated to make it a major trading centre in the island, at a moment when the traffic in sugar, rum, coffee, slaves, provisions and manufactures was reaching its peak, and when a temporary boost in profits provided by the destruction of sugar production in Saint Domingue after 1791 had left local planters flush with cash and scrambling to find ways to develop their marginal lands to take advantage of this situation. ${ }^{18}$

\footnotetext{
${ }^{14}$ The Library of Birmingham, Birmingham, UK [hereafter LB], Boulton and Watt Archives, MS
} 3147/3/494/1a, Lawson to Boulton, 29 October 1799. All quotations from the Boulton and Watt Archives are reproduced here by kind permission of The Library of Birmingham.

1535 Geo III c. 27, 28, 36. (The Laws of Jamaica (7 vols., Kingston, Jamaica, 1822-4) vol. iii, 69-76, $120-32)$

1635 Geo III c. 36 (Ibid., vol. iii, 127-8)

1739 Geo III c. 11 (Ibid., vol. iii, 231-9)

${ }^{18}$ J.R. Ward, British West India slavery, 1750-1834: the process of amelioration (Oxford; Oxford University Press, 1988) pp. 39-60; Justin Roberts, Slavery and the Enlightenment in the British Atlantic (Cambridge; Cambridge University Press, 2013) pp. 26-160; Seymour Drescher, Econocide: British slavery in the era of abolition (Chapel Hill, NC; University of North Carolina Press, 2nd edition, 2010) 
The failure of the new aqueduct, apparently for technical reasons, therefore left the new town and its shipping without any fresh water and seriously threatened its bid to keep pace with the expansion of trade. 'There is a river which runs near but is below the level of the town', one resident explained, 'and in consequence of the flowing of the side the water is [?brackish] for about a mile above the town, and there is not sufficient fall from whence the water can be conveyed within less than three miles and a half', while the town itself was built on a marsh and could not sink wells. ${ }^{19}$ Local elites therefore secured an act of the assembly in November 1799 incorporating the Falmouth Water Company, which proposed to address this issue by 'conducting, leading and conveying water from the said river into and through the said town of Falmouth', and immediately faced some of the same technological challenges as their counterparts in Britain and the United States. ${ }^{20}$ An improved aqueduct sited at a more suitable part of the river would employ old and reliable technology, but because water generates friction as it travels through pipework and therefore requires even greater elevation and distance to overcome this, creating even more friction, it was calculated that nearly four miles of conduits would be required. ${ }^{21}$

pp. 113-41. Ward (p. 48) suggests that profits in Jamaica rose from 6 to 13 per cent between 1792 and 1798.

${ }^{19}$ LB, MS 3147/3/494/1a, Lawson to Boulton, 29 October 1799 and LB, MS 3147/3/494/3, Lawson to Boulton and Watt, 18 July 1800. Ogilvie, Trelawney pp. 12-13, 42.

${ }^{20} 40$ Geo III c. 29 , 'An Act to constitute certain persons therein described a corporation or body politics for supplying the town of Falmouth in the parish of Trelawney, and the inhabitants thereof, and the shipping in the harbour of the said town, with good and wholesome water' (Laws of Jamaica, vol. iv, 28-39). Ogilvie suggests that the initiative came from important local elites in the parish vestry, who were behind these other measures for the development of the town: Ogilvie, History pp. 117-22.

${ }^{21}$ LB, MS 3147/3/494/1a, Lawson to Boulton, 29 October 1799 
Since cast iron pipes cost more than five shillings per foot, a gravity-fed system would have cost between $£ 5,000$ and $£ 6,000$ for pipework alone. ${ }^{22}$ Clearly it would be better to find a site closer to Falmouth where the water could be lifted mechanically to a sufficient height, and the directors briefly considered building a chain pump or 'Persian' waterwheel turned by wind, cattle or even the force of the river itself, which would lift the water in buckets into a stone gutter and feed it into the pipework. ${ }^{23}$ Presumably the attraction was that these too were cheap and reliable pieces of technology that were widely used on sugar mills across the island. The Jamaican planter and historian Bryan Edwards estimated that waterwheels for a large estate of roughly 600 acres cost about $£ 1,000$, including the construction of reservoirs, sluices and channels, of which about one-third was the cost of the waterwheel itself. ${ }^{24}$ However, one of the directors then suggested a third option: the hydraulic ram recently patented by Messrs Boulton and Watt and produced in the same Birmingham

\footnotetext{
${ }^{22}$ This is calculated from the figures of $£ 2,666$ and $£ 2,819$ for two miles of cast iron pipe quoted by Boulton and Watt in February 1801: LB, MS 3147/3/494/11a, Boulton and Watt to Board of Directors, 15 December 1800 and MS 3147/3/494/12, 'Trial Estimate for Charge of Ram and Pipes', c. 1800. ${ }^{23}$ LB, MS 3147/3/494/5, Board of Directors to Boulton and Watt, 19 July 1800. Ogilvie therefore appears to have been mistaken in arguing that the Persian wheel was built here from the outset, but his conclusions have been repeated in subsequent work: Ogilvie, Trelawney p. 119; Jean Besson, Martha Brae's two histories: European expansion and Caribbean culture-building in Jamaica (Chapel Hill, NC; University of North Carolina Press, 2002) pp. 76-8.

${ }^{24}$ Bryan Edwards, The history, civil and commercial, of the British colonies in the West Indies (3 vols., London, 1793-1801) vol. ii, 291-2. For the cost of waterwheels in Britain, see Stanley Chapman, 'The cost of power in the industrial revolution in Britain: the case of the textile industry', Midland History, 1 (1971) pp. 1-24. For the incidence of water-mills in Jamaica, see B. W. Higman, Jamaica surveyed: plantation maps and plans of the eighteenth and nineteenth centuries (Kingston, Jamaica; Institute of Jamaica Publications, 1988) pp. 81, 95, 102, 116-20, 123-5.
} 
foundry which turned out their steam engines. 'Having seen an account of your apparatus and the method of raising water for which you have procured a patent', James Lawson told them in October 1799, 'I am induced to believe that, by means of it, water would be raised much higher than is here required, and that it would answer our purpose in a manner superior to any other [?apparatus] ${ }^{25}$ The hydraulic ram was (and is) a simple piece of machinery, invented by the Montgolfier brothers in France in 1797 with the Swiss inventor Francois-Pierre Amis Argand, who patented the apparatus in Britain and then sold the patent to Boulton and Watt (Figure 1). ${ }^{26}$ It uses a series of valves to place water under high pressure and then drive it out of the ram with sufficient force to push the water uphill and along several miles of pipes, offering a simple and reliable means of pumping water that would cost about $£ 200$ or $£ 300$ but have lower running costs than a Persian wheel. The other directors were sceptical and their initial letter to Boulton and Watt declared that 'unless you are morally certain of the efficiency of the ram for the purposes required, and unless you can warrant its having strength and durability', they would use other methods. ${ }^{27}$

[Insert Figure 1 here]

The directors were therefore reluctantly prepared to explore new technology in Jamaica in order to create a more effective outlet for the produce of their plantations, and also to explore its applications for irrigation and sugar milling at a time when the

\footnotetext{
${ }^{25}$ LB, MS 3147/3/494/1a, Lawson to Boulton, 29 October 1799

${ }^{26}$ H.W. Dickinson, 'Early years of the hydraulic ram', Transactions of the Newcomen Society, 17 (1936) pp. 73-83

${ }^{27}$ LB, MS 3147/3/494/1a, Lawson to Boulton, 29 October 1799 and MS 3147/3/494/5, Board of Directors to Boulton and Watt, 19 July 1800. For the cost, see MS 3147/3/494/12, 'Trial Estimate for Charge of Ram and Pipes', c. 1800.
} 
island was bringing even its marginal land under cultivation in order to take advantage of high sugar prices. ${ }^{28}$ Trials had taken place in Jamaica and Saint Domingue in the 1760 s in using steam engines to pump water to feed irrigation ditches and millponds for sugar works, and parties in Falmouth were well aware that a successful experiment in the waterworks could help create a wider market for them among planters in the West Indies. ${ }^{29}$ 'I am certain that, should one of your patent engines be ordered here under the direction of a competent person, it would be the means of creating a great demand for them from this country', Lawson told Boulton and Watt, while the directors likewise noted that 'there are at this moment many proprietors of estates who, having heard of the present correspondence, are anxiously waiting the result'. ${ }^{30}$ They intended, 'should the ram be found to answer, to import several ... to perform the work which they are now obliged to do by means of cattle, and the precarious and uncertain aid of windmills'. Lawson's letters suggest that both sides saw the waterworks as their chance to test the ram under local conditions and to address any technical issues before it was marketed more widely to planters. 'I chose to defer troubling you until the work was completed', he told them in September 1803, for example, 'and until I might from experience give you a decisive [?report] upon the performance of your hydraulic ram'.31

Having received positive responses from their enquiries to Boulton and Watt, in July 1800 the committee appointed by the company placed its order for the

\footnotetext{
${ }^{28}$ See above n. 18.

${ }^{29}$ Satchell 'Steam power' pp. 222-6; McClellan, Colonialism and science pp. 70-4

${ }^{30}$ LB, MS 3147/3/494/1a, Lawson to Boulton, 29 October 1799; LB, MS 3147/3/494/5, Board of Directors to Boulton and Watt, 19 July 1800.
}

${ }^{31}$ LB, MS 3147/3/494/28, Lawson to Boulton and Watt, 4 September 1803. 
hydraulic ram and over two miles of six-inch diameter cast iron pipework to carry the water from the river to Falmouth, at a predicted cost of $£ 2,500 .^{32}$ Boulton and Watt began construction in December and contracted out with various nearby foundries for the pipework, though the rising price of cast iron made it necessary to increase the final price to nearly $£ 3,800 .{ }^{33}$ Most of the order had been completed by August 1801 and was shipped out from Liverpool and Bristol together with an engineer, William Clarke, nominated by Boulton and Watt to help set it up. The major problems only began in 1802 when the company made its preparations for installation. The original plan had been for the ram to sit about three miles from Falmouth near a waterfall on the Martha Brae, which would provide it with a sufficient head of water to drive the water along the pipes. ${ }^{34}$ Clarke boasted though 'that he could make it work in a mill pond' and sited the ram further downriver in a deep pond or basin with a set of sluices and gutters to direct water into the machine and carry away the surplus. However, because there was not a sufficient elevation or fall between the inlets and outlets to the basin the ram lacked enough of a 'head' to push the water down the pipework. ${ }^{35}$ 'The consequence was that when everything was completed and the sluices opened, the machine would not work at all', noted Lawson, 'to the great mortification of the friends of the undertaking and very much to the satisfaction of the opposers of it, who

\footnotetext{
${ }^{32}$ LB, MS 3147/3/494/5, Board of Directors to Boulton and Watt, 19 July 1800.

${ }^{33}$ LB, MS 3147/3/494/11a, Boulton and Watt to Board of Directors, 15 December 1800 and MS

3147/3/494/12, 'Trial Estimate for Charge of Ram and Pipes', c. 1800.

${ }^{34}$ LB, MS 3147/3/494/28, Lawson to Boulton and Watt, 4 September 1803.

${ }^{35}$ LB, MS 3147/3/494/30, Lawson to Boulton and Watt, 22 July 1804.
} 
now prided themselves on their sagacity in having ... predicted that the plan could never succeed' ${ }^{36}$

It was therefore not enough simply to transmit technology to Jamaica. As in Saint Domingue, Cuba or elsewhere in the Americas, inventions such as the steam engine or the vacuum pan had to be adapted to local economic and social conditions. Studies of steam power in these places by Satchell, Tomich, McClellan and others have stressed the myriad technical and mechanical skills that had to be imported or sourced locally in order to make it work, and the same was true of the hydraulic ram, but less attention has been paid to the institutional context. ${ }^{37}$ The transmission of new technology to the West Indies required not only skilled civil and mechanical engineers and artisans, as predicted by Mokyr, but also effective businessmen, lawyers and other professionals who could provide the organisational and financial framework needed to support this new technology. The experience of the Falmouth Water Company shows that when the demand for new technology was sufficiently high, the slave society of Jamaica was able to supply these necessities and even to use them skilfully and imaginatively to overcome some of the obstacles created by the process of diffusion.

-II-

The most immediate issues facing the directors of the Falmouth Water Company were technological and mechanical. The ram and its attendant structures had to be altered to generate enough water pressure, and without any assistance from William Clarke, who embodied the warning from Boulton and Watt that 'but little confidence can be

\footnotetext{
${ }^{36}$ LB, MS 3147/3/494/28, Lawson to Boulton and Watt, 4 September 1803.

${ }^{37}$ See above n. 4 .
} 
placed in the sobriety and industry of workmen whom [are] removed from under our inspection'. ${ }^{38}$ Having ignored the recommendations of both the company and the manufacturers in locating the ram, 'we found he had got to his ne plus ultra', Lawson noted, 'and could not even furnish us with a hint how to extricate us out of the present dilemma ... [and] after the failure alluded to, we ceased to consult [him]'. ${ }^{39}$ Luckily the directors were able to draw on local expertise instead. By 1804 about 40 per cent of the 800 plantations in the island used some form of water power to work the mills that ground sugar cane, and several plantations such as the Hope Estate in the parish of St Andrew's near Kingston had built extensive aqueducts, creating a body of millwrights and civil engineers who were well versed in the practical aspects of hydraulic engineering. ${ }^{40}$ As in Philadelphia and New York, the waterworks could therefore 'call upon the technical knowledge of a growing number of engineers who had learned to make surveys, take levels, construct watertight masonry, fashion steam engines, and build embankments, bridges and tunnels' ${ }^{41}$

The directors had already mooted building a dam in the river to increase the strength of the current and power the Persian wheel, so it was a simple matter to hire

\footnotetext{
${ }^{38}$ LB, MS 3147/3/494/1a, Lawson to Boulton, 29 October 1799; MS 3147/3/494/5, Board of Directors to Boulton and Watt, 19 July 1800; MS 3147/3/494/11a, Boulton and Watt to Board of Directors, 15 December 1800;, MS 3147/3/494/21, Stewart to Boulton and Watt, 5 September 1801; MS $3147 / 3 / 494 / 22$, Stewart to Boulton and Watt, 30 November 1801. Similar problems were encountered when engineers were sent overseas to maintain steam engines: see Jennifer Tann, 'Marketing methods in the international steam engine market: the case of Boulton and Watt', Journal of Economic History, 38 (1978) pp. 374-7

${ }^{39}$ LB, MS 3147/3/494/28, Lawson to Boulton and Watt, 4 September 1803.

${ }^{40}$ Satchell, 'Early use of steam power', p. 222

${ }^{41}$ Blake, Water for the cities p. 17
} 
several engineers to construct a dam at the mouth of the basin Clarke had dug so as to build up a strong enough head of water to power the ram. Lawson wrote happily in September 1803 that 'the situation was favourable for the purpose, and the result of this means was equal to our most sanguine expectations' ${ }^{42}$ The dam provided a sufficient head of water to enable the ram to pump the water nearly 40 feet uphill through two miles of pipework to the town of Falmouth, where it emptied into a stone reservoir in the town square capable of holding some 60,000 gallons. ${ }^{43}$ A further pipe and wharf carried it out to ships in the harbour but the population collected the water directly from the reservoir, a decision that spared the company the technological and commercial problems of piping water to individual homes, which Tomory has shown made such high demands on waterworks in London and Philadelphia. ${ }^{44}$ The trade-off, as noted below, were the financial problems that the company then experienced in collecting water duties. The only civil engineering issue that remained was that the basin was now so deep that the ram was usually submerged in operation, and the basin had to be drained in order to effect repairs, '[which] is a very laborious process', Lawson noted, 'but on the whole we conceive that the deviations from the original intention have been in our favour, and had Mr Clarke himself had any notion of

\footnotetext{
${ }^{42}$ LB, MS 3147/3/494/1b, Lawson to Boulton, 29 October 1799; MS 3147/3/494/5, Board of Directors to Boulton and Watt, 19 July 1800; MS 3147/3/494/28, Lawson to Boulton and Watt, 4 September 1803.

${ }^{43}$ LB, MS 3147/3/494/28, Lawson to Boulton and Watt, 4 September 1803. Ogilvie, Trelawney p. 58, 119

${ }^{44}$ Many of the technological improvements described by Tomory and others were developed to address this specific problem: see above n. 10 .
} 
procuring a fall [of water] by means of a dam and not dug the basins so deep he might undoubtedly have claimed some merit from it'. ${ }^{45}$

The successful adoption of the ram also required the application of local mechanical engineering skills to repair the frequent breakages that would otherwise have made it too unreliable to be economic to operate. 'The working gear (as must necessarily happen in any such machine) has occasionally broke', Lawson reported, 'and the parts of it which are liable to friction wear a great deal'. ${ }^{46}$ The iron valves broke several times and the leather that maintained a watertight seal frequently had to be replaced. The working gear gave way entirely in March 1804. Once again the company was able to draw on local expertise to effect repairs and even improvements. The many plantations on the island were major industrial complexes, whose mills, boiling- and distilling-houses required very large numbers of carpenters, blacksmiths, bricklayers, millwrights and other mechanical artisans. Skilled millwrights were particularly in demand, and the company's agent in London noted in November 1801 that 'it is the most lucrative business in the mechanical line of any carried on there. Any man of moderate capacity, industry and sobriety must succeed in the business. ${ }^{47}$ B.W. Higman has estimated that by 1834 at least 6 percent of the slave population or 18,000 people were tradesmen or artisans trained up by planters for this purpose. ${ }^{48}$ The island also had several large foundries that specialised in repairing plantation

\footnotetext{
${ }^{45}$ LB, MS 3147/3/494/30, Lawson to Boulton and Watt, 22 July 1804.

${ }^{46}$ LB, MS 3147/3/494/28, Lawson to Boulton and Watt, 4 September 1803.

${ }^{47}$ LB, MS 3147/3/494/22, Stewart to Boulton and Watt, 30 November 1801.

${ }^{48}$ B.W. Higman, Slave population and economy in Jamaica, 1807-1834 (Cambridge; Cambridge University Press, 1976) pp. 37-9. For white artisans, see Kamau Brathwaite, The development of Creole society in Jamaica, 1770-1820 (Oxford; Oxford University Press, 1971) pp. 42-4
} 
machinery, and combined European with African metallurgical expertise. ${ }^{49}$ Boulton and Watt were dismissive of their capacity, writing that there was no need to patent the ram in Jamaica 'as the ram can only be beneficially manufactured where there are large iron works ... [and] we are not apprehensive of rivalship from any other quarter [in Jamaica]', but Satchell and Roper have argued that by the early nineteenth century the William James Foundry in Kingston had the capacity to cast parts for steam engines and mills in the island, a job requiring high levels of competence and skill, and they therefore 'became strategically placed as a part of the support services of the sugar industry'. ${ }^{50}$ Like the foundries in the United States described by David Meyer and Richard Thompson, they may even have acted as important nodes for the transfer of mechanical skills and innovation in Jamaica. ${ }^{51}$

Indeed, the Falmouth Water Company was able to use these skills to venture beyond mere repairs to some improvements to the ram. The failure of the iron valves was an irritation, they reported, 'but having very good tradesmen on the spot we have been enabled to repair some of them, and have been advised to replace the iron valves with strong brass ones, which are already cast but not yet put on'. ${ }^{52}$ Lawson noted in his report to Boulton and Watt in July 1804 that the company had made other small

\footnotetext{
${ }^{49}$ Candice L. Goucher, 'John Reeder's foundry: a study of eighteenth-century African-Caribbean technology', Jamaica Journal, 23 (1990) pp. 39-43; Veront Satchell and Shani Roper, 'The William James Foundry 1817-43: an exposé of local metallurgical enterprise', Industrial Archaeology Review, 29 (2007) pp. 105-13.

${ }^{50}$ Satchell and Roper, 'William James Foundry', p. 112. For Boulton and Watt, see LB, MS 3147/3/494/11a, Boulton and Watt to Board of Directors, 15 December 1800.

${ }^{51}$ David R. Meyer, Networked machinists: high-technology industries in Antebellum America (Baltimore, MD; Johns Hopkins University Press, 2006); Thomson, Structures of change pp. 129-59. ${ }^{52}$ LB, MS 3147/3/494/28, Lawson to Boulton and Watt, 4 September 1803.
} 
modifications to the ram to cope with its frequent submergence in the basin and that by tweaking other parts it had been made both quieter and more efficient, though he also admitted that they still remained dependent on Boulton and Watt for any major technological improvements. ${ }^{53}$ 'Permit me to request (as any knowledge we have of managing the machine is merely practical) that, should it appear to you from your ... knowledge of the scientific principles upon which its power depends', he had told them earlier in September 1803, 'that you could furnish us with any instructions on the subject, which might facilitate or obviate the frequent occurrence of accidents'. ${ }^{54}$ When the working gear gave way entirely in March 1804 the company consequently sent back the broken parts to Boulton and Watt to be completely redesigned. ${ }^{55}$

The slave society of Jamaica was therefore not in a position to drive forward major innovations or considerable technological alterations, but as in Cuba or Saint Domingue it could use the human resources generated by the plantation system to adapt new technologies such as the hydraulic ram to local conditions and even to provide some small incremental improvements or 'micro-inventions'. As Mokyr has noted, 'effective use of technology ... required not only access and incentives to create and access new technology but also the competence to make use of it and to carry out the "instructions" contained in the blueprint of the technique', and the artisans of Jamaica were evidently as capable as those of Britain in producing 'a cumulative flow of small, incremental, unrecorded but indispensable micro-inventions that adapted inventions to local needs and circumstances and made them work

\footnotetext{
${ }^{53}$ LB, MS 3147/3/494/30, Lawson to Boulton and Watt, 22 July 1804.

${ }^{54}$ LB, MS 3147/3/494/28, Lawson to Boulton and Watt, 4 September 1803.

${ }^{55}$ LB, MS 3147/3/494/29a, Board of Directors to Boulton and Watt, 26 March 1804.
} 
better. ${ }^{56}$ The needs of sugar milling in the island produced sufficient civil and mechanical engineers and artisans with the skills to overcome the problems that the company faced, not least the limited skills of their metropolitan expert. The next section will show that Jamaica was also capable of providing a suitable institutional matrix for the adoption of this new technology.

-III-

As noted at the start, the mechanical expertise necessary for technological diffusion had to be coordinated and deployed efficiently, and massive technological projects such as waterworks had to be financially sustainable. Beginning with Sidney Pollard in the 1960s and continuing with the work of new institutional economists such as Daniel Bogart, the importance of proper structures and skills for managing these large corporate projects and regulating capital and credit has been recognised. ${ }^{57}$ One of the most important structures that reached maturity in Britain in the late seventeenth century was the joint-stock company, the direct ancestor of the modern corporate form, which combined a stable corporate structure with an open financial base. The low barriers to investment enabled joint-stock companies to raise large amounts of money and spend it effectively in order to sustain major technological projects such as

\footnotetext{
${ }^{56}$ Mokyr, The enlightened economy pp. 106-117

${ }^{57}$ Sidney Pollard, The genesis of modern management: a study of the Industrial Revolution in Great Britain (Harmondsworth; Penguin, 1968); Daniel Bogart, 'Turnpike trusts and the transportation revolution in 18th century England', Explorations in Economic History 42 (2005) pp. 479-508 and idem. 'Did turnpike trusts increase transportation investment in eighteenth-century England?', Journal of Economic History 65 (2005) pp. 439-68.
} 
canals, harbours, railways and public utilities. ${ }^{58}$ Tomory has shown that it was the standard format for waterworks in London in this period, though not in North America, where the greater political and financial demands required municipal enterprises with larger powers of taxation. ${ }^{59}$ Institutions therefore had to be aligned with local circumstances, but some form of corporate structure was necessary, and this section will argue that a slave society such as Jamaica could provide the Falmouth Water Company with the legal, political and financial resources to adapt technology such as the hydraulic ram successfully and make it economically viable.

The joint-stock company was a recent but not unfamiliar concept in Jamaica in 1799 , since one had been chartered by the house of assembly only a few years before to construct a breakwater at Montego Bay for the protection of shipping. ${ }^{60}$ The choice of a joint-stock company rather than a municipal corporation for the waterworks was probably influenced by the need to raise money without recourse to local taxation. There was no formal banking sector in the island with the resources to fund major capital projects, but by floating shares that offered not only dividends but also the

\footnotetext{
${ }^{58}$ Ron Harris, Industrializing English law: entrepreneurship and business organization, 1720-1844 (Cambridge; Cambridge University Press, 2000); Robert Wright, Corporation nation (Philadelphia, PN; University of Philadelphia Press, 2014) pp. 4-115. For examples of their role in directing investment, see W.M. Stern, 'The first London dock boom and the growth of the West India docks', Economica, 19 (1952) pp. 59-77; J.R. Ward, The finance of canal building in eighteenth century England (Oxford; Oxford University Press, 1974); M. C. Reed, Investment in railways in Britain, 1820-1844: a study in the development of the capital market (Oxford; Oxford University Press, 1975).

${ }^{59}$ For London, see above n. 10. For North America, see Blake, Water for the cities p. 30-41, 77.

${ }^{60}$ See 35 Geo. III c. 39, 'An Act to constitute certain persons therein described a corporation or body politic for making and keeping up a close harbour at Meagre Bay, being a part of Montego Bay, in the parish of St James, and for other purposes' (Laws of Jamaica, vol. iii, 81-100).
} 
chance of capital gains the company was able quickly to find subscribers for the $£ 20,000$ it required. ${ }^{61}$ 'A large sum is already subscribed for the purpose', Lawson told Boulton and Watt in October 1799 before the bill of incorporation had even passed, and the company had probably raised around $£ 4,000$ or $£ 5,000$ by 1802 , giving it the financial depth to accommodate spiralling costs. ${ }^{62}$ The directors had calculated in July 1800 that the ram and its pipework would cost at least $£ 2,500$ but the final total was closer to $£ 3,800$ as the price of cast iron increased. ${ }^{63}$ 'Had the distance between us been less, we should have thought proper to wait your concurrence in this alteration', Boulton and Watt wrote, 'but considering how much time would be lost we have judged that we should best comply with your intentions by issuing the orders without delay'. ${ }^{64}$ The funds raised by the sale of shares therefore allowed the directors to cope with this unexpected increase in costs and to dispatch a further $£ 1,200$ in October 1801, as well as to absorb the further expenses of

\footnotetext{
${ }^{61}$ There is currently no comprehensive study of sources of credit and investment at the turn of the nineteenth century, but for earlier and later periods see Sheridan, Sugar and slavery pp. 260-305; Eisner, Jamaica, $1830-1930$ pp. 195-8, 305-7. One Jamaican pound (£) was equivalent to $£ 0.60$ or $12 \mathrm{~s}$ sterling.

${ }^{62}$ LB, MS 3147/3/494/1a, Lawson to Boulton, 29 October 1799 . This is based on my estimate that $£ 10$ a share was called up in 1798 , due to the fact that the shares (nominally worth $£ 50$ each) were trading at a discount of $£ 9$ and then a premium of $£ 1310$ s $0 \mathrm{~d}$ each in 1841 , after a further $£ 210$ s per share had been called up in 1839: see 'Editorial', Morning Post, No. 239, 24 October 1839; 'Falmouth Water Company’, Morning Journal, No. 616, 12 March 1841. The company also raised $£ 700$ by selling the land around the reservoir to the city in 1802: Ogilvie, History pp. 39, 44, 45 ${ }^{63}$ LB, MS 3147/3/494/5, Board of Directors to Boulton and Watt, 19 July 1800; MS 3147/3/494/11a, Boulton and Watt to Board of Directors, 15 December 1800; MS 3147/3/494/12, 'Trial Estimate for Charge of Ram and Pipes', c. 1800.

${ }^{64}$ LB, MS 3147/3/494/11a, Boulton and Watt to Board of Directors, 15 December 1800.
} 
building and rebuilding the basin and dam thanks to Clarke's mistakes. ${ }^{65}$ The final balance of $£ 10918 \mathrm{~s} 8 \mathrm{~d}$ due to Boulton and Watt was only finally paid off in August 1805.66

The capacity of the Falmouth Water Company to adapt technology successfully to conditions in Jamaica also relied on securing and enforcing the legal powers needed to make the whole venture profitable. The act of incorporation imposed a flat rate on property owners in Falmouth of two shillings for every pound of rental value for water, and six pence per ton of tonnage on ships watering in the harbour, and the company relied on collecting these sums to maintain its financial viability ${ }^{67}$ Within a few years it was clear that defaulters were widespread and the company had to secure supplementary legislation from the assembly that tightened up procedures. ${ }^{68}$ The enacting legislation also allowed the company to purchase and hold land for the purpose of erecting pipes and reservoirs, including by compulsory purchase or eminent domain, and authorised its agents to trespass on neighbouring land for the purpose of construction and maintenance on making due satisfaction. ${ }^{69}$ As in Britain and North America during the industrial revolution, where 'it was virtually impossible to construct a waterworks system unless provision was made for taking property through the exercise of the right of eminent domain', the wider

\footnotetext{
${ }^{65}$ LB, MS 3147/3/494/24, Campbell to Boulton and Watt, 12 October 1802, and MS 3147/3/494/26, Campbell to Boulton and Watt, 16 November 1802.

${ }^{66}$ LB, MS 3147/3/494/32, Campbell to Boulton and Watt, 27 August 1805.

6740 Geo III c. 29, ss. xiv, xv, xx.

${ }^{68} 40$ Geo III c. 29, ss. xiv; 49 Geo III c. 26, 'An Act for the more effectual recovery of the tax payable to the directors of the Falmouth Water Company' (Laws of Jamaica, vol. v, 164).

${ }^{69} 40$ Geo III c. 29 , ss. x, xii, xiii.
} 
success of the water company and its technology depended on the capacity of the legislature to override private property rights in the public interest. ${ }^{70}$ The legislature also helped the company to police its new technology and prevent people tampering with the aqueducts, by creating fines of $£ 500$ for persons putting or placing 'any earth, stones, ashes, dirt, dust, rubbish or filth of any sort, or anything else whereby the water may be polluted, injured or affected', or damaging the pipes, aqueducts and or reservoirs. $^{71}$ The power and support of the assembly was therefore a necessary precondition for the wider commercial success of the hydraulic ram.

Finally, individuals were important. As will have become clear by now, James Lawson was instrumental in introducing the company to Boulton and Watt, pushed for the introduction of the hydraulic ram, and bullied the directors into persisting with it despite the initial failure in September 1803. At a subsequent meeting of the board, the directors initially voted by a large majority to lay the ram aside. ${ }^{72}$ 'Two only (myself being one), who had a confidence in the justness of the principle on which the ram was constructed ... [and] prevailed with the others', Lawson noted, '(as a heavy expence had been already incurred) to go a little further and try if a dam might not obviate all our disappointment' ${ }^{73}$ He also dug deeper into his own pocket to support the project. 'The ignorance and blunder of Mr William Clarke had at one time

\footnotetext{
${ }^{70}$ For the importance of compulsory purchase and legislative power in Britain and North America, see Julian Hoppit, 'Compulsion, compensation and property rights in Britain, 1688-1833', Past \& Present, 210 (2011) pp. 93-128 and Daniel Bogart, 'Property rights and Parliament in industrialising Britain’, The Journal of Law \& Economics 54 (2011) pp. 241-74. The quotation is from Blake, Water for the cities pp. 70-1.

${ }^{71} 40$ Geo III c. 29 s. xvii, xix, xxii.

${ }^{72}$ LB, MS 3147/3/494/28, Lawson to Boulton and Watt, 4 September 1803.

${ }^{73}$ LB, MS 3147/3/494/28, Lawson to Boulton and Watt, 4 September 1803.
} 
rendered the completion of our undertaking so improbable that shares in our stocks were selling under par', he noted, and to prevent confidence collapsing he had been forced to buy up another 40 or so shares, probably costing him around $£ 200$ or $£ 300 .{ }^{74}$ Individuals therefore exercised an important influence in Jamaica and elsewhere; as James McClellan has noted, the introduction of a steam engine to Saint Domingue in 1786 to irrigate the Arbitonite region - 'the most advanced application of technology to the problem of irrigation' - was driven forward by a local planter and official, Bertrand de Saint-Ouen, and collapsed when he died the following year. ${ }^{75}$ They formed part of the wider matrix of institutional factors that did not differ in any real sense from those available in Britain or North America, and enabled the waterworks at Falmouth to turn their new technology into an effective and profitable investment.

-IV-

The experience of the Falmouth Water Company and its hydraulic ram between 1799 and 1805 therefore shows that the island of Jamaica had the human and institutional capacity to support technological diffusion and innovation, not despite the plantation system and slave society but largely because of it. 'Our project from the beginning was by many considered visionary', Lawson noted to Boulton and Watt in September 1803 , '[and] ... your own experiences of the prejudices generally opposed to every public-spirited improvement, and the adoption of new invention will suggest to you

\footnotetext{
${ }^{74}$ LB, MS 3147/3/494/28, Lawson to Boulton and Watt, 4 September 1803. This assumes, for reasons noted above in $n .63$, that $£ 10$ had been subscribed per share and that they were trading at 25 to 50 per cent below their market value at this point.

${ }^{75}$ McClellan, Colonialism and science pp. 73-4.
} 
that it was not without much difficulty and the utmost persuasion that we have been enabled to bring our object to a happy termination', but once this had been overcome through the efforts of James Lawson and others the resources of Jamaican society could be mobilised to bring the project to fruition. ${ }^{76}$ The crucial factor was the contribution that the ram might offer not only to the development of Falmouth but also by assisting irrigation and sugar milling in a period when planters in Jamaica were opening up marginal lands to take advantage of high sugar prices; as Gudmestad has noted, slavery could serve as a filter for the economic choices, made in this case by the planters and merchants of Falmouth. ${ }^{77}$ This eventually proved sufficient to overcome any lingering prejudice against new technology and to enable the normal operation of supply and demand to resume, by drawing on the civil and mechanical skills and human capital created by the plantation system and the legal and political structures that had evolved to help govern the slave society. As in Cuba or Saint Domingue, planters in Jamaica were thus capable of considerable technological adaption and ambition when the proper combination of circumstances was found.

This can best be demonstrated by the failure or reversal of technological diffusion across the Americas as either demand or supply fell out of alignment. In New York, for example, the construction of the steam engine and pumps in the city in 1774 was abandoned when war broke out two years later, and the city consequently relied on wells and horse-driven pumps until the early nineteenth century. ${ }^{78}$ Though the new steam engines initially proved workable in Philadelphia, their high running costs and uncertain reliability meant that they had to be replaced by a system of

\footnotetext{
${ }^{76}$ LB, MS 3147/3/494/28, Lawson to Boulton and Watt, 4 September 1803.

${ }^{77}$ See above n. 9.

${ }^{78}$ Blake, Water for the cities pp. 83-120; Koeppel, Water for Gotham pp. 70-101
} 
waterwheels in 1822 at a cost of $\$ 430,000$, which proved sufficient for the city for over 30 years. ${ }^{79}$ The technological and scientific advances in Saint Domingue were wiped out by an extended pattern of rebellion and warfare after 1791 and by the exclusion of the Haitian Republic from regular trade networks after 1804. 'The fact that Haiti in the nineteenth century was not the scientific or colonial center Saint Domingue had been in the eighteenth', notes McClellan, 'makes it clear that in this case at least, institutes of science marched at the vanguard, not the rear guard, of colonialism' ${ }^{80}$ As one of the first towns in the western hemisphere to use machinery to pump water for urban consumption - beaten only by New York and Philadelphia the town of Falmouth likewise had the potential to act as a crucial bridgehead for the wider diffusion of the technology of the hydraulic ram through Jamaica and the West Indies, but this was never achieved because both the demand for innovation and the capacity of the island to supply it very rapidly fell back out of alignment. ${ }^{81}$

Although the letters from the waterworks to Boulton and Watt ceased in 1805, there were already signs that demand for the ram might not meet the expectations that both sides had entertained. Boulton and Watt agreed from the outset that the ram was particularly appropriate for the waterworks 'under your peculiar circumstances', but added that 'we are of opinion there are but few situations in which the application of the steam engine might not be preferable. It requires no head or fall of water ... and the power of it is equally applicable to the raising of water for the purposes of irrigation and to the turning of all kinds of millwork and machinery, ${ }^{82}$ Planters were

\footnotetext{
${ }^{79}$ Blake, Water for the cities pp. 78-98

${ }^{80}$ McClellan, Colonialism and science p. 289 and, more broadly, pp. 289-97.

${ }^{81}$ LB, MS 3147/3/494/28, Lawson to Boulton and Watt, 4 September 1803.

${ }^{82}$ LB, MS 3147/3/494/9, Boulton and Watt to Board of Directors, 15 December 1800.
} 
therefore encouraged to invest in the new steam engines, which were more flexible and useful, and presumably also more profitable for Boulton and Watt. The years after 1815 also saw the economies of Jamaica and the British West Indies enter a slow but very prolonged decline in the face of competition from Cuba, Martinique and other regions in the Americas that had embraced technology such as the vacuum pan and enjoyed lower labour costs, leaving the planters in Jamaica with little money to spare for technologies such as the hydraulic ram that offered only marginal benefits in productivity or efficiency. ${ }^{83}$ Skilled labour grew scarcer and more expensive after the abolition of the slave trade in 1807 , probably making it much harder to maintain the machinery of the waterworks. By 1839 the company had long since replaced the ram with the simpler and perhaps more reliable chain pump or Persian wheel that they had first envisaged, though a steam engine was also installed in 1841 to assist this older technology when the level of the river fell too low. ${ }^{84}$ This wheel still stands in Falmouth today, at the basin where the hydraulic ram was installed in 1802, a reminder that technological diffusion could move backwards as well as forwards as the circumstances of slave societies such as Jamaica changed.

\footnotetext{
${ }^{83}$ For economic and demographic conditions after 1815, see Eisner, Jamaica pp. 163-98; William A. Green, British slave emancipation: the sugar colonies and the great experiment, 1830-1865 (Oxford; Oxford University Press, 1991) pp. 191-229.

84 'Editorial', Morning Post, No. 239, 24 October 1839; 'Falmouth Water Company', Morning Post, No. 598, 19 February 1841; 'Falmouth Water Company’, Morning Journal, No. 616, 12 March 1841. For the wheel, see Ogilvie, History p. 119.
} 


\section{Figure 1: The Hydraulic Ram}

[See attached Figure1.jpg]

Source: H.W. Dickinson, 'The early years of the Hydraulic Ram', Transactions of the Newcomen Society 17 (1936) p. 77, (C) The Newcomen Society for the Study of the History of Engineering and Technology, reprinted by permission of Taylor \& Francis Ltd, www.tandfonline.com, on behalf of The Newcomen Society for the Study of the History of Engineering and Technology.

\section{$\underline{\text { Acknowledgements }}$}

I am grateful to James Robertson, Gad Heuman and the reviewer for Slavery \& Abolition for their comments and advice on this piece. The research for this article was funded by a British Academy Postdoctoral Fellowship and Jesus College, Oxford, with further support from a Leverhulme Early Career Fellowship and University College London

\section{Disclosure Statement}

There are no potential conflicts of interest. 